\title{
Aryl hydrocarbon receptor activity may serve as a surrogate marker for MS disease activity
}

\section{OPEN}

Joseph J. Sabatino Jr,

MD, PhD

Scott S. Zamvil, MD, $\mathrm{PhD}$

Correspondence to

Dr. Sabatino:

jsabatino@ucsf.neuroimmunol. org or Dr. Zamvil:

zamvil@ucsf.neuroimmunol.org

Neurol Neuroimmunol Neuroinflamm

2017;4:e366; doi: 10.1212/ NXI.0000000000000366
See article
MS diagnosis and prognosis is based on a combination of clinical criteria, MRI, and CSF findings. However, we still lack the ability to predict disease course, including relapse frequency and disability progression. Thus, reliable biomarkers of MS risk and prognosis are sorely needed. In this issue of Neurology ${ }^{\circledR}$ Neuroimmunology \& Neuroinflammation, Rothhammer et al. ${ }^{1}$ suggest that changes in serum agonistic activity of the aryl hydrocarbon receptor (AHR) may be a useful measure of MS activity.

The AHR is a ligand-activated transcription factor that was initially described in response to toxins, but was later found to be activated by a multitude of diverse stimuli, including environmental toxins, microbial toxins, dietary compounds, and endogenous metabolites. ${ }^{2}$ The AHR is found on a host of immune cells, including $\mathrm{T}$ cells and $\mathrm{B}$ cells, and is found at particularly high levels in barrier tissues such as the gut, skin, and lungs. ${ }^{2}$ A number of endogenous AHR ligands have been reported, including kynurenine (a tryptophan metabolite produced by indoleamine 2,3-dioxygenase), indoles (produced by bacterial metabolism of tryptophan and dietary intake), and 6-formylindolo[3,2-b] carbazole. ${ }^{2}$ Depending on the ligand, AHR stimulation can strongly influence the development of proinflammatory Th17 or antiinflammatory regulatory $\mathrm{T}$ cells, leading to profoundly different outcomes in the MS animal model, experimental autoimmune encephalomyelitis (EAE). ${ }^{3,4}$ The AHR is therefore a putative MS therapeutic target in MS. In this regard, laquinimod can alter the phenotype of antigen-presenting cells and autoreactive $T$ and $\mathrm{B}$ cells, ${ }^{5-8}$ and its therapeutic efficacy in EAE is dependent on AHR activation. ${ }^{9}$ AHR stimulation in the CNS also seems to have a neuroprotective effect in EAE. ${ }^{10}$ It therefore stands to reason that AHR activity could provide a link between environmental exposures, genetics, and MS risk and disease activity.

In a study by Rothhammer et al., ${ }^{1}$ serum AHR agonistic activity in patients with MS using a reporter assay driven by an AHR-responsive promoter was measured. They first demonstrated that AHR agonistic activity was reduced in a cohort of patients with relapsing-remitting MS (RR-MS) compared with healthy controls. The authors then measured AHR activity in MS patients with different stages of disease activity. Surprisingly, they found that AHR agonistic activity was lower in patients with MS in remission compared with those with active inflammation (as confirmed by contrast-enhanced MRI), although both groups were still lower overall compared with controls. By contrast, AHR activity levels were higher in patients with clinically isolated syndrome at the time of their first clinical attack compared with healthy controls, whereas no difference was found between patients with benign MS (long-standing RR-MS with minimal neurologic impairment) and controls.

The findings by Rothhammer et al. are the first indication that AHR activity is dynamically modulated at various stages of MS. In addition to representing a potential biomarker of MS activity, the AHR is also a novel therapeutic target for MS, as in the case of laquinimod.5,6 The reason why AHR agonistic activity is increased during a first clinical attack, but decreased in subsequent relapses remains unclear. The authors did not identify any association between AHR agonistic activity and patient age, disease duration, or status on approved MS therapies. However, one must recognize that the patient numbers in their cohorts were relatively small. It is possible that AHR agonist levels may be influenced by factors other than MS activity. The reporter assay used by the authors captures the sum of all AHR agonistic activity in the sera but does not measure individual AHR ligands, which can vary markedly in their effects on the immune system. ${ }^{3,4}$ Thus, these findings may represent changes in endogenous AHR ligand levels in response to inflammation, differences in patient microbiota, or other extrinsic environmental sources. As the study by Rothhammer et al. was not longitudinal, it is not clear to what extent AHR levels

From the Multiple Sclerosis Center, Department of Neurology, University of California San Francisco.

Funding information and disclosures are provided at the end of the editorial. Go to Neurology.org/nn for full disclosure forms. The Article Processing Charge was funded by the Editorial Office.

This is an open access article distributed under the terms of the Creative Commons Attribution-NonCommercial-NoDerivatives License 4.0 (CC BY-NC-ND), which permits downloading and sharing the work provided it is properly cited. The work cannot be changed in any way or used commercially without permission from the journal. 
fluctuate throughout the course of individual patients with MS. It is also unknown whether changes in the AHR agonistic activity drive changes in MS activity or represent a compensatory response. Further study into the dynamic changes of specific AHR ligands and fluctuations during different stages of disease activity within individual patients and larger populations as a whole is clearly needed. It is hoped that such studies will shed light on the utility of AHR as a possible biomarker and therapeutic target in MS. The findings by Rothhammer et al. represent an exciting step forward toward realizing this goal.

\section{STUDY FUNDING}

No targeted funding reported.

\section{DISCLOSURE}

Dr. Sabatino received research support from NMSS, R25 NS070680. Dr. Zamvil served on the data safety monitoring board for BioMS, Teva Pharmaceuticals, Eli Lilly and Com; is a member of the clinical advisory board for Myelin Repair Foundation; is deputy editor for Neurology: Neuroimmunology \& Neuroinflammation; has a patent pending for Aquaporin-4 peptides and methods for using the same; has consulted for Biogen, Teva, EMD Serono, Novartis, and Roche; served on the speaker's bureau for Biogen and Advanced Health Media; and received research support from Biogen, Teva, NIH, NMSS, and Alexander M. and June L. Maisin Foundation. Go to Neurology.org/nn for full disclosure forms.

\section{REFERENCES}

1. Rothhammer V, Borucki DM, Sanchez MIG, et al Dynamic regulation of serum aryl hydrocarbon receptor agonists in MS. Neurol Neuroimmunol Neuroinflammation 2017;4:e359. doi: 10.1212/NXI.0000000000000359.
2. Stockinger B, Di Meglio P, Gialitakis M, Duarte JH. The aryl hydrocarbon receptor: multitasking in the immune system. Annu Rev Immunol 2014;32:403-432.

3. Quintana FJ, Basso AS, Iglesias AH, et al. Control of T (reg) and $\mathrm{T}(\mathrm{H}) 17$ cell differentiation by the aryl hydrocarbon receptor. Nature 2008;453:65-71.

4. Veldhoen M, Hirota K, Westendorf AM, et al. The aryl hydrocarbon receptor links TH17-cell-mediated autoimmunity to environmental toxins. Nature 2008;453:106109.

5. Schulze-Topphoff U, Shetty A, Varrin-Doyer M, et al. Laquinimod, a quinoline-3-carboxamide, induces type ii myeloid cells that modulate central nervous system autoimmunity. PLoS One 2012;7:1-10.

6. Jolivel V, Luessi F, Masri J, et al. Modulation of dendritic cell properties by laquinimod as a mechanism for modulating multiple sclerosis. Brain 2013;136:1048-1066.

7. Varrin-Doyer M, Pekarek KL, Spencer CM, et al. Treatment of spontaneous EAE by laquinimod reduces Tfh, B cell aggregates, and disease progression. Neurol Neuroimmunol Neuroinflammation 2016;3:e272. doi: 10.1212/ NXI.0000000000000272.

8. Toubi E, Nussbaum S, Staun-Ram E, et al. Laquinimod modulates $\mathrm{B}$ cells and their regulatory effects on $\mathrm{T}$ cells in Multiple Sclerosis. J Neuroimmunol 2012;251:45-54.

9. Kaye J, Piryatinsky V, Birnberg T, et al. Laquinimod arrests experimental autoimmune encephalomyelitis by activating the aryl hydrocarbon receptor. Proc Natl Acad Sci USA 2016;113:E6145-E6152.

10. Rothhammer V, Mascanfroni ID, Bunse L, et al. Type I interferons and micorbial metabolites of tryptophan modulate astrocyte activity and central nervous system inflammation via the aryl hydrocarbon receptor. Nat Med 2016; 22:586-597. 


\title{
Neurology \\ Neuroimmunology \& Neuroinflammation
}

\author{
Aryl hydrocarbon receptor activity may serve as a surrogate marker for MS disease \\ activity \\ Joseph J. Sabatino, Jr and Scott S. Zamvil \\ Neurol Neuroimmunol Neuroinflamm 2017;4; \\ DOI 10.1212/NXI.0000000000000366
}

This information is current as of June 16, 2017

\begin{abstract}
Updated Information \&
including high resolution figures, can be found at:

Services

http://nn.neurology.org/content/4/4/e366.full.html

References

This article cites 10 articles, 3 of which you can access for free at: http://nn.neurology.org/content/4/4/e366.full.html\#\#ref-list-1

Permissions \& Licensing

Information about reproducing this article in parts (figures,tables) or in its entirety can be found online at:

http://nn.neurology.org/misc/about.xhtml\#permissions

Reprints

Information about ordering reprints can be found online:

http://nn.neurology.org/misc/addir.xhtml\#reprintsus
\end{abstract}

Neurol Neuroimmunol Neuroinflamm is an official journal of the American Academy of Neurology.

Published since April 2014, it is an open-access, online-only, continuous publication journal. Copyright

Copyright $\odot 2017$ The Author(s). Published by Wolters Kluwer Health, Inc. on behalf of the American

Academy of Neurology.. All rights reserved. Online ISSN: 2332-7812.

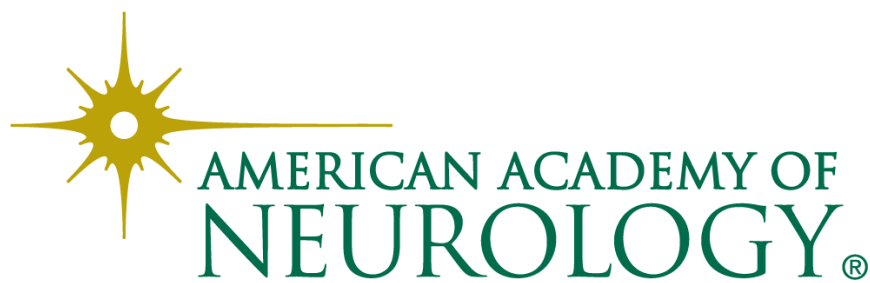

